University of Wollongong

Research Online

Faculty of Law, Humanities and the Arts Papers (Archive)

Faculty of Arts, Social Sciences \& Humanities

$1-1-2015$

Capitalism, regulation theory and Australian labour law: Towards a new theoretical model

Brett Heino

University of Wollongong, bjh202@uowmail.edu.au

Follow this and additional works at: https://ro.uow.edu.au/lhapapers

Part of the Arts and Humanities Commons, and the Law Commons

Research Online is the open access institutional repository for the University of Wollongong. For further information contact the UOW Library: research-pubs@uow.edu.au 


\title{
Capitalism, regulation theory and Australian labour law: Towards a new theoretical model
}

\begin{abstract}
This article employs the methodology of the Parisian regulation approach to periodise Australian capitalism into distinct models of development. Within such models, labour law plays a key role in articulating the abstract capitalist need to commodify labour-power with the concrete realities of class struggle. Given the differential ordering of social contradictions and the distinct relationship of social forces within the fabric of each model of development, such formations will crystallise distinct regimes of labour law. This is demonstrated by a study of the two successive models of development that have characterised Australian political economy since the post-Second World War era: antipodean Fordism (1945 to mid-1970s) and liberal-productivism (late-1980s to the present). The result of this examination is a model of legal analysis that, although tailored to the Australian experience, is capable of application in other contexts.
\end{abstract}

\section{Keywords}

model, theory, australian, capitalism, labour, regulation, law, towards, theoretical

\section{Disciplines}

Arts and Humanities | Law

\section{Publication Details}

B. Heino, 'Capitalism, regulation theory and Australian labour law: Towards a new theoretical model' (2015) 39 (3) Capital and Class 453-472. 


\section{Capitalism, Regulation Theory and Australian Labour Law:}

\section{Towards a New Theoretical Model}

\section{Brett Heino}

\section{University of Wollongong, Faculty of Law, Humanities \& the Arts}

Abstract: This article employs the methodology of the Parisian Regulation Approach to periodise Australian capitalism into distinct models of development. Within such models, labour law plays a key role in articulating the abstract capitalist need to commodify labourpower with the concrete realities of class struggle. Given the differential ordering of social contradictions and the distinct relationship of social forces within the fabric of each model of development, such formations will crystallise distinct regimes of labour law. This is demonstrated by a study of the two successive models of development which characterised Australian political economy since the post-World War II era; antipodean Fordism (1945mid-1970s) and liberal-productivism (late-1980s-present). The result of this examination is a model of legal analysis that, although tailored to the Australian experience, is capable of application in other contexts.

\section{$\underline{\text { Introduction }}$}

The end of the post-World-War II 'long boom' in the mid-1970s proved the beginning of a process of political-economic change that has fundamentally altered and reformulated the institutions of Australian industrial relations, particularly the regime of labour law which underpins them. Labour law during the boom unified a permissive attitude towards organised labour, bargaining between capital and labour at a broad occupational level, a series of institutions which diffused wage gains from leading sectors and the growth of administrative fixes to heightened worker power. From the mid-1980s onwards, however, this regime was 
usurped by another which combines hostility to trade unions, a destruction of the conciliation and arbitration system, a severing of the institutional links homogenising the wage structure and associating productivity and wage growth and an intensified juridification on the back of the increased valency of market forces.

Despite the significance of this shift, the nature of legal change remains poorly theorised. Both labour law and industrial relations remain disciplines beholden to a distinctly empiricist method (Treuren, 1997a: 59; 2000: 75). Even the development within Australian scholarship of the 'Labour Market Regulation Approach' (see, for example Arup et al, 2006) has largely failed to provide a rigorous account of the political economy of legal change beyond the recognition that neo-liberalism has materially altered the parameters of industrial relations (Quinlan, 2006: 21-42). This inability to explain the articulations between legal change and the deep structures of Australian capitalism is apparent even in broader political economy work that explicitly seeks to do so (such as Mack, 2005). Here, the source of the poor theorisation of legal change is not so much an empiricist method as a static conception of law as an element of a reactive superstructure (forewarned by Pashukanis, 1978: 53-55; Collins, 1982: 30-34; for notable exceptions in the Australian setting, see Fraser, 1978; Wells, 1989). Similarly, and although generative of much discussion, conceptual and methodological flaws dog more recent approaches to the study of labour law institutions, such as the 'Varieties of Capitalism' (VOC) and 'Legal Origins' (LO) schools.

What is necessary for a rigorous account of labour law development, and legal change more broadly, is a Marxist analysis that reconciles both the abstract and concrete functions and structures of law within the capitalist mode of production. Although there are a variety of important contributions to a Marxist theory of the law (see, for example, Renner, 1949; Pashukanis, 1978; Fraser, 1978; Kay \& Mott, 1982; Fine, 1984; Miéville, 2006), ${ }^{\mathrm{i}}$ most have tended to emphasise the abstract place of law within capitalism. Although perhaps partly a 
function of the abstract language which characterised many of the Marxist debates of the 1970s and 1980s, the more important determinant of this focus would appear to be the lack of a sophisticated, nuanced account of capitalist change and evolution. If one cannot understand the unfolding of capitalism's abstract tendencies into disparate concrete forms, any account of law must perforce operate at the abstract level and, in so doing, elide the complexity of capital's temporal existence.

The Parisian Regulation Approach (PRA) is the body of theory which has most fruitfully tackled the task of explaining the dialectical relationship between capitalism's abstract tendencies and concrete structures. As we shall explore in greater detail below, the PRA represents an effort to generate an intermediate level analysis of capitalist development that, whilst taking the methodological lead from Marx, employs discrete concepts operating at a lower level of abstraction (Neilson, 2012: 160). If it were unified with the more sophisticated works of Marxist jurisprudence, such as Pashukanis (1978), Kay \& Mott (1982) and Fine (1984), the PRA would be a tool of considerable analytic power in understanding how the tendencies and contradictions of capital are differentially inscribed in the legal form as part of distinct epochs of capitalist development. Unfortunately, however, the potential of the PRA for legal analysis appears almost entirely untapped. The author was unable to find any examples of explicitly legal study from a regulationist perspective. In Australia, this shortcoming is doubled, given that the PRA has, barring a few significant exceptions (Broomhill, 2008; Lloyd, 2002, 2008; Heino, 2013), made little headway in Australian political economy scholarship.

It is into this lacuna that this article steps. Drawing upon the methodology of the PRA, this article periodises Australian political economy since World War II into two models of development, historically specific crystallisations of capitalist social relations unifying an industrial paradigm, accumulation regime and mode of regulation (Lipietz, 1992: 1-3). These 
models, whilst derived from regulationist ideal-typical frameworks, have been sensitised to the Australian context and thus display a unique institutional materiality and distinctive trajectories of crisis. The models identified are antipodean Fordism (1945-mid-1970s) and liberal-productivism (mid-1980s-present), separated by a period of crisis characterised by 'institutional searching' to navigate an escape therefrom (Heino, 2013: 160). Each model possesses an order of labour law appropriate to it, depending upon the differential articulation of the contradictions of capitalist social relations, the integration of organised labour, the valency of market forces and the diffusion of the commodity form. These orders are not passive, functional responses to the needs of capital. Instead, they are historically contingent structures in which the abstract function of the commodification of labour-power (Kay \& Mott, 1982: 110-114) is buffeted by class struggle and the attempt to impress the competing political economies of labour and capital upon the legal form (Lebowitz, 2003: 77-100).

This demonstration will hopefully serve two purposes; one of focus and one of concept. Regarding the former, this paper will introduce to the readers of Capital \& Class an Australian perspective on labour law change and PRA models, which has hitherto remained unexplored, both within this journal and generally. Turning to the latter, the theoretical understanding developed here, although tailored to the Australian experience, can be retroengineered by modifying its more concrete concepts. In this way, it can be applied to other Fordist/liberal-productivist societies specifically, whilst the general union of the PRA and Marxist jurisprudence can be extended to other epochs outside of this conjuncture.

\section{The Parisian regulation approach: an overview and key concepts}

Readers of Capital \& Class will no doubt be aware of the genealogy of the PRA and the debates that have arisen around its epistemology, concepts and methods. ${ }^{\text {ii }}$ However, given 
that I, following Neilson (2012), argue for the need to return the PRA to its roots in a thoroughly Marxist political economy, ${ }^{\mathrm{iii}}$ it is necessary to revisit this history briefly.

The PRA emerged in France in the late-1970s, stemming from Aglietta's (1979) pathbreaking account of the development of American capitalism. Derived from structural Marxism, it nevertheless rejected the Althusserian conception of social reproduction as quasiautomatic (Jessop \& Sum, 2006: 37). Instead, regulationists emphasised the inherently improbable character of capital accumulation; a function of the contradictions inscribed in capitalist social relations (Jessop \& Sum, 2006: 37). The necessary question in light of this characterisation was how capitalism could be made stable for periods of time, as was the case in the post-War decades.

The answer was regulation. Capital accumulation, and the tendential laws governing it, can be guided and regularised through a contingent, historically variant combination of economic and extra-economic factors in a distinctive institutional matrix, vitiating, deferring or displacing the various contradictions encoded in capitalism's DNA and reproducing the capitalist mode of production (Aglietta, 1979: 15-17; Tickell \& Peck, 1995: 360). As Aglietta (1979: 16) states 'The study of capitalist regulation...is the study of the transformation of social relations as it creates new forms that are both economic and noneconomic, that are organized in structures and themselves reproduce a determinant structure, the mode of production.'

Such institutional fixes to the paradoxes of capitalist social relations achieve only a provisional and temporary measure of success. Regulation cannot absolve capitalism of its contradictions; indeed, the attempt to regulate particular paradoxes tends to exacerbate others, unleashing disequilibria which ultimately undermine the coherence of any particular regulatory phase (Tickell \& Peck, 1995: 360; Harvey, 2010: 119-139). The resultant crisis 
threatens the stability and sustainability of capital accumulation, which can only be restored with the development of new regulatory structures and norms.

Regulationists have developed a set of sophisticated concepts to explain the constituent structures of a system en régulation. These are an:

- Industrial paradigm-a dominant model of labour process organisation, governing the social and technical division of labour. A prime example is mass-production on semiautomatic assembly lines (Aglietta, 1979: 116-122);

- Accumulation regime-a macro-level articulation of production and consumption reproducible over a long-period (Jessop, 2013: 8). Depending upon its articulation of Department 1 (producing means of production) and Department 2 (producing means of consumption), such a regime can be extensive or intensive (Aglietta, 1979: 71-72);

- Mode of regulation-an ensemble of norms and institutions that can stabilise an accumulation regime (Jessop \& Sum, 2006: 42). It includes the form of the wagelabour-nexus, state structures, modalities of competition, the money form and insertion into the international economy; and

- Model of development-a coherent combination of an industrial paradigm, accumulation regime and mode of regulation (Lipietz, 1992: 1-3).

With the notion of a model of development, the PRA is ideally placed to deliver a mid-range Marxist account of the evolution of capitalism in all its national guises (Neilson, 2012: 160). As described previously, this potential has remained largely untapped within Australian scholarship. This is particularly unfortunate for labour law and industrial relations work, given the analytical sophistication the PRA could infuse into study in these areas (Treuren, 1997b: 362). By elucidating not only the correlation between economic and extra-economic forces, but the actual modes of their articulation and co-constitution within evolving capitalist 
social relations, the PRA opens the way to a more holistic understanding of contemporary issues in industrial relations and labour law. Armed with PRA methodology and concepts, we can see the developments in these fields as the result of both the structural tendencies of the abstract capitalist mode of production and the contingency of its concrete forms; a useful rejoinder to the identified shortcomings of analysis.

Indeed, it is in acknowledging the dialectical relationship between the abstract and the concrete that the PRA represents a significant advance over contemporary approaches to labour law change, such as VOC and LO. Whilst the former acknowledges the role of law generally, and labour law specifically, in differentiating between different national capitalisms (typologised broadly as 'liberal market economies' and 'coordinated market economies'; Hall \& Soskice, 2001), it takes as its conceptual foundation the relational firm, rather than the contradictions of capitalist social relations. Although outlining well enough the role law plays in constituting work relations in stationary societies, VOC lacks an account of endogenous social change (Boyer, 2005: 539); it is therefore incapable of describing legal development in response to the developing tendencies and contradictions of capitalism. The LO is even more static, describing the nature of labour regulation as a function of a country's legal history, namely whether it belongs to the common or civil law tradition (Botero et al, 2004). Considering the time-scale involved, LO demands deep path-dependencies (Ahlering \& Deakin, 2007: 867) that verge on legal determinism. Such an approach is even more unsuited than VOC in accounting for legal change within the past several decades, and both compare poorly to the PRA's utility in this endeavour.

As identified previously, most Marxist accounts of the law are also insufficient in the task of explaining legal change, albeit for different reasons. These will be addressed in greater detail when we come to outline labour law under capitalism more specifically. 


\section{Fordism and liberal-productivism: ideal-typical models}

Using the above concepts, regulationists have generated ideal-typical models of development. The model for which the PRA is most well-known (or perhaps notorious) is Fordism. Fordism has variously been used to describe a labour process, an accumulation regime, a mode of regulation or model of development. Although conceptual slippage sometimes dogs regulationist work, most of the confusion arises outside of a regulationist paradigm (Boyer, 1990: ix-xix; Hampson, 1991: 115, 122-124). We must thus unfold this notion precisely.

According to Lipietz (1992: 3-7), the Fordist model of development combined a Taylorist, mechanised labour process paradigm within large, multi-department firms, an autocentric mass production/mass consumption intensive accumulation regime synthesizing full employment with rising productivity and real wages, and a mode of regulation involving a redistributivist welfare state that guaranteed effective demand through protective social legislation and the generalisation of mass consumption norms. This model provides a substantive understanding of the physiology of the post-War boom, particularly its mechanisms of coherence and potentialities for crisis. ${ }^{\text {iv }}$

Due to a combination of inter-related features, including the exhaustion of productivity growth in lead sectors, resistance of workers to intensified exploitation, the internationalisation of production and the erosion of US hegemony (Braverman, 1974: 31-35; Aglietta, 1979: 119-122; De Vroey, 1984: 55-63; Lipietz, 1992: 14-23), Fordism began to lose coherence from the early-1970s onwards, reflected in high inflation, growing unemployment and stumbling productivity growth. This period extended into the 1980s, and was characterised by 'institutional searching' to escape the growing crisis and restore stable accumulation (Heino, 2013: 160). 
In the early to mid-1980s, the ideology of neo-liberalism progressively imposed an intellectual order upon these unfolding events (Jessop, 1988: 163) and armed capital with the resources to attempt to shape a new model of development. Of course, purposive action often leads to unintended results in complex social systems, whilst accidental discoveries and experiments can produce institutions of unexpected functionality (Lipietz, 1987). Moreover, the program of capital had to contend with the political economy of labour, which is dialectically entwined with, but distinct from, that of capital's (Lebowitz, 2003: 77-100).

However, by the late 1980s to early 1990s, the elements of a new model had come into existence. These cohered into a system Lipietz (2013) dubs liberal-productivism. This model unifies a fractured industrial paradigm (which combines the extension and intensification of Taylorism in the tertiary sector with islands of 'negotiated involvement' on the part of workers) with an intensive accumulation regime that disassociates real wages and productivity (and is thus debt-fuelled) and a neo-liberal mode of regulation in an increasingly complex global division of labour (Lipietz, 2013: 129-130) This system remains on foot today, although the Global Financial Crisis arguably represented the beginnings of its terminal crisis (Ivanova, 2011:330).

Each model structured the various contradictions of capitalist social relations in a distinct fashion. Whereas Fordism took the wage-labour nexus as the site of primary contradiction (institutionalising wages as a source of effective demand and integration of organised labour as conducive to social stability: Jessop, 2013: 14), liberal-productivism both inverts this nexus (conceiving of wages as a cost of international production) whilst transfiguring capitalism's other contradictions (such as substituting competition in place of monopolist regulation: Jessop \& Sum, 2006: 329-331). Each model thus represents an historically conditioned crystallisation of the contradictions of capitalist social relations. 
It is important to note that these ideal-typical models are the result of a process of abstraction which, in the manner of Marx, 'brings out and fixes the common element' but apprehends 'no real historical stage' (Marx, 1973: 85-88). The ideal-typical model of development does not describe the concrete experience of any particular society. Rather, as Treuren (1997a: 60-61) notes, it forms a vital intermediate link in the movement from abstract to concrete. It enters into a dialectical relationship with concrete existence in which the model identifies causal relationships whilst empirical study comments on the adequacy of the theoretical construct (Treuren, 1997a: 61).

Thus, these models need sensitising to the Australian context if they are to fulfil their analytical potential (Treuren, 1997b: 362, 366). Similar modification will be necessary in applying these categories to any other concrete society falling within the Fordist/liberalproductivist ideal-types.

\section{$\underline{\text { Antipodean Fordism and liberal-productivism }}$}

Applying the stylised features of Fordism to the Australian experience of the post-War boom reveals a model of development that, whilst recognisably Fordist, modifies some of its key abstract components. The Australian incarnation of Fordism combined:

- An industrial paradigm based on mass production but marked by an incomplete incorporation of Taylorist forms of work control and organisation (Wright, 1993) with;

- An intensive accumulation regime of mass production and mass consumption which was not autarkic; that is, it was premised upon the ability of the export-oriented farming and mining sectors to underwrite high levels of industrial protection (Bell \& Head, 1994: 10-13); and 
- A mode of regulation that precociously enshrined the Fordist wage-labour nexus in the arbitration system. This mode, although guaranteed by a Keynesian Welfare National State (KWNS), was characterised by the unification of that state's economic and social objectives/functions (Castles, 1994: 123-124).

The author has dubbed this model of development antipodean Fordism (a term coined by Rolfe, 2003, who, however, uses it as a vague cultural construct: Heino, 2014). It builds upon the features of the 'Australian mode of development' Treuren (1997b: 366) hinted at whilst more clearly systematising it in line with discrete PRA concepts. ${ }^{\mathrm{v}}$

Unlike Fordism, the liberal-productivist ideal-typical model requires less modification to capture the Australian experience, given the fact that it is constituted by an explicitly global production system that corrodes the ability of states to control a nationally bounded economic and political space (Lipietz, 1992: 43-46; Jessop, 1997: 303-306, 2013: 8-9). Although important continuities with antipodean Fordism are present (like the reliance upon primary commodity exports and a dependence on foreign capital), it is in liberal-market economies like Australia, the US and UK that liberal-productivism has found purest expression (Jessop, 2013: 16; he uses the term 'finance-driven accumulation').

Now that the features of antipodean Fordism and liberal-productivism are in hand, we can move to a consideration of the labour law regimes that characterised them. We must first, however, gain an understanding of labour law within capitalist society generally. Although it has been necessary to first outline the contours of the PRA and its novel application to the Australian context, the proper starting point for any investigation into the structure and dynamic of labour law must begin with capitalist social relations in the abstract. ${ }^{\mathrm{vi}}$ It is to these we now turn.

\section{A method of legal analysis}


Beginning the analysis into the structure and function of labour law within the capitalist mode of production means immediately encountering the main lines of debate within Marxism concerning a distinct theory of the law. As alluded to previously, a crude, instrumentalist Marxism would regard law merely as capital's class power cloaked in an ideological veil (Collins, 1982: 29-30; Heino, 2013: 151). Although law undoubtedly plays an ideological role, such a view is incapable of explaining why power relations take a legal form (Pashukanis, 1978: 74-75) and how protective legislation, such as occupational health and safety and unfair dismissal statutes, comes into being.

More sophisticated Marxist legal analysis rejects instrumentalism, instead locating the legal form as deeply implanted within capitalist social relations. Pashukanis (1978) developed a brilliant but flawed account of the formal equality and ostensible neutrality of bourgeois law, ${ }^{\mathrm{vii}}$ a juridical product giving effect to the proprietary recognition needed for commodity exchange. Following Pashukanis' lead, derivationist theorists sought to logically derive the forms and functions of the capitalist state, including its juridical order, from the structure of the capital relation (see, for example, Holloway \& Picciotto, 1978). Law was broadly conceived in Pashukanis' terms, except that its formal equality and fetishistic positing of individuals as de-classed juridical equals was more explicitly located within capitalist production, as opposed to exchange, relations (Blanke, Jürgens \& Kastendiek, 1978). The less sophisticated examples of this approach tended to assume the functionality of the forms so derived. Moreover, the derivation exercise itself was largely static, a one-dimensional account of law as the manifestation of capital's tendencies (see, for example, Altvater, 1978).

As Jessop (1988: 155) describes, however, other derivationist work problematized the relationship between form and function and, in so doing, admitted of a more dynamic relationship binding the two. Although the former may broadly be inscribed in capitalist social relations, the contradictions that generate these forms constantly undercut their 
effectiveness whilst generating pressures they cannot adequately contain. Indeed, as Althusser (1977) and Jessop (2013) have noted, these contradictions are internally variegated, such that different poles of each contradiction (including those that determine the legal regime) assume varying weight in different historical conjunctures. Moreover, capitalist class relations, and the structures and experiences that constitute them, produce a proletarian political economy that, although dialectically entwined with that of capital's, is nevertheless distinct from it (Lebowitz, 2003: 77-100).

What a rigorous Marxist theory of law must accomplish then, is a dual movement that both recognises the roots of the abstract legal form within capitalist social relations whilst at the same time accounting for the overdetermination of its concrete manifestations. This process would begin by tracing the most abstract features of the legal form within the capitalist mode of production. These features are to be considered the structural horizons of capitalist law, determining broadly what it can and cannot be whilst at the same time affording a wide space for the historical contingency consequent upon the interactions and overdeterminations of capitalism's tendencies. Moving down the hierarchy of abstraction, and following Jessop (2013), the next step in the analysis would involve ascertaining how these forms are ordered and hierarchized within distinct epochs of development. It is at this level that the PRA comes into its own, particularly through the model of development concept, which can grasp the ramifications this order of forms poses for the law. Finally, at the most concrete level of investigation, an understanding must be gained as to how the concrete law of a model of development simultaneously crystallises its own unique configuration of capitalism's abstract tendencies, and relates to the trajectories of crisis it opens.

This methodology is suitable both as a total method of legal analysis and a more specific inquiry into various substructures of law. Labour law, as the crucial juridical moment in the commodification of labour-power, is particularly worthy of such an inquiry. 


\section{Labour law under capitalism-structure and struggle in the abstract}

Unlike previous class systems, the economic and extra-economic moments of exploitation within capitalism are temporally and spatially divisible (Wood, 2003: 9-14). This substitutes mediated, impersonal and bureaucratic relations of exploitation in place of the personal bonds of dependency that characterised slave and feudal societies, as well as separating producers from their means of subsistence (Poulantzas, 1978: 63-65, 86-87; Kay \& Mott, 1982: 81-83; Wood, 2003: 9-25). Capitalism, moreover, is a mode of production premised upon the universalisation of market relations. Although the market has been an ancillary institution in human societies ever since production outstripped subsistence needs, it is only within capitalism that market trade becomes the beginning point and destination of all economic activity (Polanyi, 1944: 43). As Marx (1990: 178) noted, the enormous expansion of commodity relations entailed by capital requires mutual recognition of proprietary right on the part of commodity buyers and sellers; the violence and robbery that characterised feudal society, for example, would not be commensurable with the day-to-day conduct of a market system. This order, in turn, must formally be beyond the ability of any one commodity owner or seller to corrupt for their own purpose (Pashukanis, 1978: 138-144). ${ }^{\text {viii }}$ This reality is the material basis of the legal form; a framework of social relations characterised by abstract, universal and formal norms that together comprise an axiomatic system (Poulantzas, 1978: Kay \& Mott, 1982; Fine, 1984). At a certain stage of development, this form becomes merged with the capitalist state, a related though distinct form also implanted in capitalism's DNA (Fine, 1984: 146-154). As Fine (1984: 134-154) notes, these are both considered juridic forms of capitalism, distinct from capital as an economic form yet equally rooted in the capitalist mode of production. ${ }^{\text {ix }}$

Labour law, derived from this abstract form, is responsible for ensuring the continued reproduction of labour-power as a commodity (Kay \& Mott, 1982: 110-113), reiterating 
Thompson's (1977: 261) point that law is deeply imbricated within production relations.

Within its fabric, however, there exists an insoluble contradiction; that between reconciling the formal equality of commodity exchange (Pashukanis, 1978: 62-64) with the reality of exploitation (Kay \& Mott, 1982: 111, 119). The result is a legal order that is shot through with all the tensions of capitalist social relations (Kay \& Mott, 1982: 111). The integration of a collective historical subject (the proletariat) into the legal process ensures the law itself becomes an arena of class struggle in which the competing political economies of labour and capital struggle for the higher ground.

Kay \& Mott (1982: 131-133) have plotted this process as a 'law-administration' continuum. The growth of working-class power ensures that the capitalist state is forced to put out the spot-fires of proletarian struggle through the development of administrative fixes, ad hoc responses that supplement the universality of law through addressing specific issues (Kay \& Mott, 1982: 132). Although initially distinct from law, these are given legal form and come to be part of a legal-administrative totality.

Given the tendency of different modes of development to crystallise capitalist contradictions in distinct hierarchised patterns, and the different potentialities this opens for the exercise and integration of working-class power, it follows that the trajectory and substance of this continuum will be both a product and a presupposition of the model of development of which it is part.

\section{$\underline{\text { Antipodean Fordism and labour law }}$}

As mentioned previously, the site of primary contradiction within Fordism was the wagelabour nexus, the process of socialisation of productive activity within capitalism (Boyer, 2002: 73-74). More specifically, Fordism encoded this wage-labour nexus into a distinct form, namely, the growth of real wages and employment security in line with expected 
productivity increases and the intensification of labour (Bertrand, 2002; 80-82; Boyer, 2002: 75). For this nexus to function, a set of distinct legal and institutional conditions were required, namely those that allowed for the diffusion of wage increases from highproductivity 'lead sectors,' permitted collective and 'connective' bargaining (Boyer, 1990: x), encouraged the organisation of labour and developed a notion of the 'standard,' full-time employment contract (Burgess \& Campbell, 1998: 33). These could be considered the abstract features of labour law appropriate to the Fordist model of development.

Antipodean Fordism was unique in terms of the precocious institutionalisation of this nexus. Indeed, in the materiality of the compulsory conciliation and arbitration system it exceeded the ideal-typical model in terms of the integration of labour into the state and the law. The Australian system of conciliation and arbitration was complex, but could broadly be described as a set of quasi-judicial, formally neutral arbitral tribunals that could compulsorily determine disputes between employers and unions, with the resulting determinations called awards. $^{x}$ This structure proved exceedingly adept at articulating real wages and productivity growth within key sectors and then, through the machinery of the award system, diffusing these gains throughout the labour force. Such a mechanism is a key moment in the Fordist mode of regulation. The stability of effective demand, and with it the stability of Fordist intensive accumulation, depended upon the coherence and (relative) homogeneity of the wage structure (Boyer, 2001:165). This coherence was ensured by institutions linking highproductivity 'lead' sectors with the economy and labour force at large. In Australia, the arbitration system was better placed to deliver these outcomes than in other Fordist countries, largely through the pyramidal structure of the award system.

Cochrane (1988) observes the process at play in the post-War years, with militant unions in the metal trades, mining and stevedoring applying 'plant by plant duress' to individual employers; concessions, once granted, could 'flow-on' to other sectors of the economy. This 
was particularly the case with the metals industry, an archetypal Fordist lead sector. Well into the late-1960s, the Metal Trades Award was at the apex of the award system, with tribunal decisions about wage margins for skill being founded upon it. Respondents to other federal awards would then have their own award varied accordingly, whilst state tribunals would generally follow the lead of their federal counterpart. Even after the advent of the 'Total Wage' in 1967 (which abolished the traditional practice of determining a 'Basic Wage' and wage margins separately), the metals sector was at the forefront of wage increases and flow-ons and was a key site of the wage explosion of the early-1970s (Bramble, 2008: 41$71)$.

This tendency for the Fordist wage-labour nexus to take root in the Australian arbitration system was further expedited by the notion of 'comparative wage justice,' which enshrined the view that equal work should be equally recompensed regardless of industrial location (Provis, 1986: 25). Such an ideology was a powerful force of wage homogeneity when inserted into the fabric of the award system.

Another element of antipodean Fordism that directly shaped the modality of labour law was its unification of the economic and social policy goals of the Australian KWNS. Unlike many other Fordist countries, where a comprehensive system of social support married to a large public sector was used to deliver the government's welfare objectives, the Australian state (in both its Federal and State forms) used the arbitration system as a vehicle to deliver both economic and social policy. It was this reality that led to Castles' (1994) description of the 'wage-earners welfare state,' in which the keys to the state's redistributive and social support functions were gained through industrial citizenship. With the dissemination of 'occupational welfare benefits' (Castles, 1994: 127-128) through the award system, the Australian KWNS, in concert with the dominance of manufacturing under intensive 
accumulation, tended to produce the relatively homogenous, compressed wage structure typical of Fordism.

The fact that the mode of regulation peculiar to the antipodean Fordism largely subsumed the economic and social functions of the KWNS into the quasi-judicial system of wage regulation heightened the fundamentally contradictory nature of labour law explicated by Kay and Mott (1982: 111). That antipodean Fordism combined this necessarily contradictory structure with broader social and economic imperatives could not help but exacerbate this tension, particularly insofar as it encouraged an identity of economic/social performance with the regulation of the labour market. This was a tendency that pronounced itself strongly in the crisis of antipodean Fordism from the mid-1970s onwards, where the source of malaise was often located in the award system and trade union militancy.

Labour law under antipodean Fordism was also influenced by the latter's encouragement of moderate trade unionism, itself one of the purposes of the original Conciliation and Arbitration Act 1904 (s2(vi)). The arbitration system itself can be viewed as an institutionalised class compromise between labour and capital (Lloyd, 2002: 238), one that fixed a pronounced institutional role for labour within the fabric of labour law. Indeed, Justice Higgins, the famous second President of the original Court of Conciliation and Arbitration, (1915: 23) had noted that 'without unions, it is hard to conceive how arbitration could be worked.' The integration of organised labour into the labour law system was itself contradictory, however, in the sense that it placed the union movement in a position whereby it could use its strength to extract concessions from the state (Heino, 2013: 158-159). Throughout the post-War years, this often saw the state putting out the spot-fires of workingclass discontent, which ranged from campaigns for a reduction in work hours, higher pay, gender equality, occupational health and safety improvements and industrial democracy (Bramble, 2008: 46-62). The administrative fixes this entailed constantly threatened to 
abrade the power of capital and the stability of accumulation. In the full employment economy of post-War Fordism, this reality contained latent within it the potential of arbitration becoming maladaptive for capital. Indeed, the nature of the arbitration system itself during the Fordist era was a hallmark of the intensified power of proletarian struggle, with the strict judicial workings of the tribunal abandoned in a series of amendments in 1947 and 1956, which encouraged less formalism and greater specialist input through the appointment of 'lay' commissioners (Frazer, 2002: 29-32). ${ }^{\mathrm{xi}}$ In the event, dysfunction set in through the trade union movement subverting arbitration through collective over-award bargaining, often at the shopfloor level (Dabscheck, 1994: 146-150; Bramble, 2008: 69). This usurpation of one of the key institutions of antipodean Fordism was one of the levers of its crisis.

In short, the features of the order of labour law appropriate to antipodean Fordism reflected and crystallised its unique structuring of capitalism's contradictions, particularly its construction of the wage-labour nexus. In practice, the elements of the system - namely compulsory arbitration, encouragement of moderate unionism, the unification of wage and social objectives and the growth of administrative fixes to worker power - ensured its coherence whilst also containing disequilibria. The crisis of antipodean Fordism from the mid-1970s onwards was simultaneously the crisis of this order of labour law.

\section{Liberal-productivism and labour-law}

Liberal-productivism reorders the abstract contradictions of capitalism, both in terms of their significance vis-à-vis others and their concretisation in new structures. A key change is the inversion of the Fordist wage-labour nexus, which is reconstructed as a cost of international production (Jessop, 2013: 18). This inversion, together with the destruction of the manufacturing base of domestic intensive accumulation (Ivanova, 2011:339) saw the 
association between productivity and real wage growth that Fordism had fostered destroyed, reducing the relevance of productivity gains in dynamic sectors to the wage structure at large. Instead, the gap between increased productivity and stagnating real wages was pocketed by capitalists (Cowgill, 2013: 2-6). For this to be achieved, the institutions of the antipodean Fordist wage-labour nexus had to be modified or dismantled, particularly those elements that afforded labour the opportunity to leverage gains won in key sectors to the workforce at large. The fragmentation and decentralisation of bargaining and the destruction of the pyramidal structure of the award system (whereby developments in pace-setting awards tended to result in derivative adjustments in other awards) are key moments in the substitution of a liberal-productivist labour law regime in place of its Fordist predecessor.

The need to hamstring the ability of organised labour to make common cause is also a result of the inversion of the antipodean Fordist wage-labour nexus. The dysfunction of the latter manifested itself in a wave of industrial militancy in the late-1960s and early-1970s which often pressed against and outside the established legal and administrative channels (Bramble, 2008: 41-71). The threat this posed to the continued valorisation of capital, and the related strain this placed on the state's ability to formalise labour-power, necessitated mechanisms by which the unification and solidarity of the proletariat (a development that Fordism continually tends toward: Aglietta, 1979: 121) could be disrupted. Labour law, at the forefront of the commodification of labour-power and the construction of labour as a subject, is crucial in this endeavour. This tendency was the driving force behind a legal climate that became increasingly hostile towards trade unionism, firstly by breaking the most militant sections of organised labour (such as the deregistration of the powerful Builder's Labourers Federation in 1986) and then through gradually severing the institutionalised links between trade unionism and the conduct of industrial relations. It is in this light that the movement towards the individualisation of workplace relations must be read (Gould, 2010). 
The decline of working-class power that has generally been a feature of liberal-productivism is itself a force that impinges upon the form and content of the labour law regime. As Kay and Mott (1982: 132-133) note, the growth of proletarian power forces the state to formalise labour-power through new and creative administrative fixes. The greater the collective power and mobilisation of the working-class, the more the state is compelled to resort to such fixes to ensure the continued reproduction of wage labour. The erosion of trade union power and the intensified atomisation of the proletariat into competing units agglomerated around separate capitals reduces the ability of the working-class to pressure the state in this fashion; administrative fixes give way to an increasing penetration of the legal form narrowly construed, the form in which capital has always operated most comfortably. In the Australian experience of liberal-productivism, this reality has seen a continual state retreat from direct administrative regulation of the labour market, partly substituted by an increasing juridifcation of work relations that constructs the labour-capital relationship in the fetishised image of abstract, de-classed juridical equals engaged in mutually beneficial exchange (Poulantzas, 1978: 86-87). Juridification, which I construct as the subsumption of administrative fixes beneath the abstract legal form, is, on this score, merely the concrete expression of the reduced need of the state to spawn institutional fixes to proletarian struggle. It also represents a reconfiguration of the law-administration continuum in which the centre of balance is shifted towards law.

This legal fetish was most graphically demonstrated by the conservative Howard Government's creation of statutory individual contracts in 1996, dubbed Australian Workplace Agreements. Such agreements essentially opted employees out of the award system (subject to a weak 'No-Disadvantage' test), ${ }^{\text {xii }}$ with collectively determined awards (often overseen by specific trade unions) being supplanted by simplified, often pro forma, individual arrangements that often cut pay and conditions (Peetz, 2006: 85-115). Although 
phased out after the Labor Party won office in 2007, AWAs had inflicted grievous damage in key areas of union strength, particularly mining, and had marginalised the federal arbitral tribunal (then called the Australian Industrial Relations Commission) and the collectivist industrial relations it represented.

Juridification is organically related to the increased valency of market forces within the liberal-productivist model of development consequent upon its explicit positioning of competition as a principle of social organisation (Petit, 1999: 229-233). The advent of this mode has seen a hitherto unprecedented commodification of areas of social life previously insulated from the commodity form (Ivanova, 2011: 340, 347). Despite his inadequate conception of labour law, Pashukanis (1978) was correct in highlighting the role of exchange relations in the development of a legal form characterised by abstraction and formal equality. The greater the colonisation of market forces within all elements of the social body, the more important will be the purpose of law in providing a 'medium of association' between commodity purchasers and sellers (Fine, 1984: 142). ${ }^{\text {xiii }}$

Within the framework of Australian liberal-productivism, this process of juridification has tended towards the diminution/destruction of the quasi-administrative configuration of labour law and its replacement by a more generalist regime that both enshrines individual rights over and above collective rights and channels labour disputes through the courts of common law or a weakened tribunal (Ludeke, 1998: 869). In the 1980s and 1990s, this process manifested itself as an increasing sidelining of the arbitral tribunals, with militant employers at Mudginberri, Dollar Sweets and Australian Airlines (to name several notable examples) breaking trade union power through the imposition of archaic common-law industrial torts and the use of statutory secondary boycott prohibitions. Indeed, the severe 1998 maritime dispute (sparked by Patrick Stevedores efforts, supported by the Howard Government, to deunionise the waterfront) proceeded almost entirely through the Federal and High Court 
system, as opposed to the Australian Industrial Relations Commission. From the 1990s onwards, the labour law structure itself came to be transformed, as the state sought to recast the labour market as no different to any other commodity market. This process, lubricated by over a decade of conservative government rule, ${ }^{\mathrm{xiv}}$ culminated in the Workplace Relations Amendment (WorkChoices) Act 2005 ('WorkChoices'), which essentially recast the constitutional basis of Federal Government workplace regulation ${ }^{\mathrm{xv}}$ and rendered the federal arbitral tribunal a toothless tiger.

It is true that the succeeding Labor government's Fair Work Act 2009 does dispense 'with the more egregious manifestations of individualisation introduced by the Howard Government' (Creighton, 2011: 142) and makes the operating environment of trade unions somewhat less harsh than it was under WorkChoices. However, the species of collectivism it encourages is a parochial one, centred on the enterprise and enshrining the individual worker as the repository of many ostensibly collective rights (Creighton, 2011: 142-144). It follows WorkChoices in relegating trade unions to one of a number of participants in the conduct of industrial relations (Hardy \& Howe, 2009: 323), which addresses the dysfunction of the Fordist wage-labour nexus by disrupting the unification of the proletariat (Aglietta, 1979: 121). In short, contra suggestions that the Fair Work Act represents a re-collectivisation of Australian labour law, it is better conceived as part of the experimental 'roll-out' of liberalproductivist structures (Peck, 2010: 22-23) whereby the needs of the new model of development are reconciled with the limits of political legitimacy (O’Connor, 1973).

Lastly, the decline of the antipodean Fordist mode of regulation, and its unique combination of economic and social policy objectives under the aegis of the arbitration system, has led to a usurpation of the predominance of labour law in constituting labour-power (although this remains its sole abstract aim). Liberal-productivism's attack upon the precocious antipodean Fordist wage-labour nexus has fundamentally crippled the ability of this nexus to deliver 
wide-ranging policy goals. In its place there has arisen a more functionally differentiated welfare system and a wage relationship that is increasingly sensitive to legal regulation outside of labour law narrowly construed. For example, occupational health and safety law, conditions attached to welfare provision and the law of contractual association between business units are now important determinants of industrial outcomes for Australian workers. This reality has been grasped empirically by the Australian 'Labour Market Regulation Approach,' albeit in a theoretically impoverished way.

In place of antipodean Fordism, liberal-productivism unleashes forces that attack the efficacy and solidarity of collective labour through a reformulation of the wage-labour nexus, reduce the need of the state to develop administrative fixes to class struggle and increase the valency of market forces through an extension of the commodity form. These both constitute, and are constituted by, the qualitatively distinct labour law regime of liberal-productivism.

\section{Conclusions}

This paper attempts to apprehend in a theoretically rigorous manner the nature of the changes in Australian labour law over the past several decades. This is achieved through a process that begins with the abstract functions of law generally, and labour law specifically, within capitalist social relations. It is at this level that most Marxist accounts of the law have operated.

In order to understand at a more concrete level the manifestations of these abstract forms in the Australian context, the concepts and methodology of the PRA are deployed, modifying regulationist ideal-typical models of development to take into account the idiosyncrasies of the Australian experience. Based upon their ordering of the contradictions of capitalist social relations, the nature of organised labour's insertion into the institutional fabric, the potentialities for the exercise of collective labour's power and the valency of market forces, 
antiopodean Fordism and liberal-productivism both fix the abstract function of labour law and the legal form in distinct concrete structures. This understanding is critical in both exposing the causal relationships linking law to the evolution of Australian capitalism and identifying opportunities to mobilise counter-strategies to the disempowering (for labour) nature of legal change over recent decades. This latter point is especially significant when it is realised that liberal-productivism is, like any arrangement of capitalist social relations, unstable and dialectically evolving. Although it has addressed some of the key crisis tendencies of antipodean Fordism, it sets in motion others, particularly the threat of underconsumption consequent upon stagnating earnings and a polarised wage structure (Vidal, 2013: 468). Moreover, the fact that Australian labour is less thoroughly integrated into the institutional architecture of the state and its labour law regime could potentially open up pathways to new and dynamic forms of working class struggle, particularly considering the bureaucratic trade unionism arbitration encouraged.

More broadly, the analytical synthesis between the PRA and a sophisticated Marxist understanding of law provides a model of legal theorising that can be applied in other contexts to capture the dynamic, dialectical relationship between capital's abstract juridic forms and their historical crystallisation.

\section{Acknowledgments}

I am grateful to Yvonne Apolo, Andrew Frazer, Di Kelly and two anonymous referees for comments which considerably strengthened the argument. This research received no specific grant from any funding agency in the public, commercial, or not-for-profit sectors. 


\section{Notes}

i It still remains a fair observation, however, that the law itself has generally been of peripheral interest to
Marxist work generally.
ii Indeed, many of these debates have been played out in the pages of this journal. See, for example, Bonefeld (1987), Jessop (1988) and Holloway (1988). I do not intend to reopen this debate; suffice it to say here that I find myself in agreement with the regulationist articulation of structure and strategy (Jessop, 1988: 156-159), its retroductive ontology and epistemology (Jessop \& Sum, 2006: 300-304) and above all the method of articulating capitalism's long-run tendencies with its intermediate trajectories (Neilson, 2012: 160).

iii Neilson (2012: 161) is completely correct in drawing attention to the increasing eclecticism of the PRA under the ideological leadership of Robert Boyer. In a 2002 collection detailing the state of the regulationist program, one short chapter was devoted to the school's linkages with Marxism, and that was as concerned with distancing the school from its Marxist heritage as embracing it (Nadel, 2002). Moreover, in seeking rapprochement with the VOC school, Boyer has essentially destroyed the regulationist notion of Fordism through confusing ideal-typical models with their concrete application (Boyer, 2005: 514-516).

iv It is important to note, however, the limitation of the concept. It is certainly not reducible to massproduction and government intervention in the economy, which appears to inform the description of post-war industrialisation in developing countries as 'peripheral Fordism' (Jessop \& Sum, 2006: 156-160).

$\checkmark$ This explicit construction of antipodean Fordism and liberal-productivism in-line with discrete PRA concepts is what separates the approach taken in this paper from other regulationist-influenced Australian scholarship. Broomhill $(2008)$ and Lloyd $(2002,2008)$, whilst inspired in part by regulationist concepts and methodology, are more eclectic, amorphous and lack the neat analytical structure inherent in the model of development concept. This in part derives from ascribing to the PRA a supposed economistic perspective. Whilst perhaps true as a matter of historical focus (Jessop \& Sum, 2006: 43-44), it does not reflect any inherent limitation of the approach. Instead, this asymmetrical perspective must be corrected by a deepening and intensification of the PRA method.

vi This is the proper starting point of any rigorous regulationist analysis. Jessop \& Sum rightly argues that the increasing eclecticism of the school threatens this methodology (2006: 244-245).

vii Although Pashukanis correctly identified that the law's form is a product of the social relations into which it is embedded, he focussed exclusively on exchange relations as the source of this form, which runs counter to Marx's emphasis on the predominance of production relations.

viii This is not to suggest that groups of capitalists cannot corrupt the legal order to further their ends. However, this understanding is incidental to a formal understanding of law within capitalism. Echoing Marx's effort to understand the labour theory of value through commodities being sold at their value (Marx, 2004: 104), we must comprehend 'unadulterated' law in its class terms if we are to explain the link between law and capital in anything more than an incidental fashion.

ix In this regard Fine's (1984) conceptualisation is to be preferred to Jessop's. Although Jessop acknowledges the necessity of starting analysis with the contradictions of the capital relation (2013: 6-9), this understanding sits uneasily with his notion of the 'ecological dominance' capital generally exerts over other 'sub-systems', including the law (Jessop \& Sum, 2006: 284-287). At a theoretical level, such a conception would seem to demand that these other sub-systems are logically prior to, or independent of, capitalist social relations, whose dominance is a contingent, provisional matter. Such a view runs counter to Marx's effort to explain a mode of production as a totality, a totality internally differentiated by economic, political and ideological forces which are nevertheless grounded in the same matrix of social relations.

${ }^{x}$ For the Federal Government, the power of compulsory arbitration resides in s 51(35) of the Australian Constitution.

${ }^{x i}$ This point demonstrates how it is useful to consider administration as a practice as well as a series of structures. If Kay \& Mott (1982) err, it is in emphasising the latter view.

xii This test provided that an AWA could not undercut the relevant award. In practice the test was weakly applied, and was removed altogether under the WorkChoices legislation.

xiii The intensification of the competition principle also informs the increasing dismemberment of internal labour markets and corporate short-termism as Australian, and world, capitalism becomes increasingly financialised, a function of liberal-productivism being unable to solve periodic crisis of overproduction (Kettell, 2006). This is highly significant for the structure of the wage-labour nexus, but space prevents 
further consideration here.

xiv The conservative Liberal Party/National Party Coalition ruled from 1996-2007.

${ }^{x v}$ WorkChoices recast workplace regulation as a product of the corporations power (s51(20) of the

Constitution) in place of the arbitral power. This enormously expanded the breadth of federal regulation at the same time it destroyed one hundred years of constitutional practice. 


\section{References}

Aglietta, M (1979) A Theory of Capitalist Regulation: The US Experience, NLB, London.

Ahlering, B \& Deakin, S (2007) 'Labor Regulation, Corporate Governance, and Legal Origin: A Case of Institutional Complementarity?’ Law \& Society Review, 41(4), pp. 865908.

Althusser, L (1977) For Marx, NLB, London.

Altvater, E (1978) ‘Some Problems of State Interventionism' in Holloway, J. \& Picciotto, S (eds) State and Capital: A Marxist Debate, Edward Arnold, London, pp. 40-42.

Arup, C. Gahan, P. Howe, J. Johnstone, R. Mitchell, R \& O’Donnell, A (eds) (2006) Labour Law and Labour Market Regulation, The Federation Press, Sydney.

Bell, S \& Head, B (1994) ‘Australia’s political economy: Critical themes and issues’ in S.

Bell \& B. Head (eds) State, Economy and Public Policy in Australia, Oxford University Press, Melbourne.

Bertrand, H (2002) 'The wage-labour nexus and the employment system' in R. Boyer \& Y. Saillard (eds) Régulation Theory: The State of the Art, Routledge, London, pp. 80-86.

Blanke, B. Jürgens, U. \& Kastendiek, H (1978) 'On the Current Marxist Discussion on the Analysis of Form and Function of the Bourgeois State' in Holloway, J. \& Picciotto, S (eds) State and Capital: A Marxist Debate, Edward Arnold, London, pp. 108-147.

Bonefeld, W (1987) 'Reformulation of state theory’ Capital \& Class, 11(3), pp. 96-127.

Botero, J. Djankov, S. La Porta, R. Lopez-de-Silanes, F. \& Shleifer, A (2004) 'The Regulation of Labor' Quarterly Journal of Economics, 119(4), pp. 1339-1382. 
Boyer, R (1990) The Regulation School: A Critical Introduction, Columbia University Press, New York.

Boyer, R (2001) 'Wage formation in historical perspective: the French experience' in B. Jessop (ed) The Parisian Regulation School, Edward Elgar pp. 148-167.

Boyer, R (2002) 'Perspectives on the wage-labour nexus' in R. Boyer \& Y. Saillard (eds) Régulation Theory: The State of the Art, Routledge, London, pp. 73-79.

Boyer, R (2005) 'How and why capitalisms differ' Economy and Society, 34(4), pp. 509-557.

Bramble, T (2008) Trade Unionism in Australia: A history from flood to ebb tide, Cambridge University Press, Port Melbourne.

Braverman, H (1974) Labor and Monopoly Capital: The Degradation of Work in the Twentieth Century, Monthly Review Press, New York and London.

Broomhill, R (2008) ‘Australian Economic Booms in Historical Perspective' Journal of Australian Political Economy, 61 pp. 12-29.

Burgess, J \& Campbell, I (1998) 'Casual Employment in Australia: Growth, Characteristics, A Bridge or a Trap?' Economic and Labour Relations Review, 9(1) pp. 31-54.

Castles, F (1994) 'The Wage Earners' Welfare State Revisited: Refurbishing the Established Model of Australian Social Protection, 1983-93' Australian Journal of Social Issues, 29(2) pp. 120-145.

Cochrane, P (1988) 'Doing Time' in V. Burgmann \& J. Lee (eds) Making A Life: A People's History of Australia Since 1788, McPhee Gribble/Penguin Books,

Collins, H (1982) Marxism and Law, Clarendon Press, Oxford. 
Cowgill, M (2013) ‘A Shrinking Slice of the Pie,' ACTU, Working Australia Papers No. 1. Creighton, B (2011) ‘A Retreat from Individualism? The Fair Work Act 2009 and the Recollectivisation of Australian Labour Law' Industrial Law Journal, 40(2) pp. 116-145.

Dabscheck, B (1994) 'The arbitration system since 1967' in S. Bell \& B. Head (eds) State, Economy and Public Policy in Australia, Oxford University Press, Melbourne, pp. 142-168.

De Vroey, M (1984) ‘A regulation approach interpretation of contemporary crisis' Capital \& Class, 8(2) pp. 45-66.

Fine, B (1984) Democracy and the Rule of Law, The Blackburn Press, New Jersey.

Fraser, A (1978) ‘The Legal Theory We Need Now’ Socialist Review, 40/41, pp. 147-187.

Frazer, A (2002) 'The Federal Conciliation and Arbitration Power: from Cradle to the Grave?' Research Paper No. 15 2001-2002, Department of the Parliamentary Library Information and Research Services.

Gould, A (2010) 'The Americanisation of Australian Workplaces' Labor History, 51(3) pp. 363-388.

Hall, P \& Soskice, D (2001) Varieties of Capitalism: The Institutional Foundations of Comparative Advantage, Oxford University Press, New York.

Hampson, I (1991) 'Post-Fordism, the "French Regulation School”, and the Work of John Mathews’ Journal of Australian Political Economy, 28 pp. 92-130.

Hardy, T \& Howe, J (2009) 'Partners in Enforcement?: The New Balance Between Government and Trade Union Enforcement of Employment Standards in Australia' Australian Journal of labour Law, 22(3), pp. 306-336. 
Harvey, D (2010) The Enigma of Capital and the Crises of Capitalism, Profile Books, London.

Heino, B (2013) 'The state, class \& occupational health and safety: locating the capitalist state's role in the regulation of OHS in NSW' Labour \& Industry, 23(2) pp. 150-167.

Heino, B (2014) 'Regulation theory and Australian labour law: from antipodean Fordism to liberal-productivism' $28^{\text {th }}$ AIRAANZ Conference (Melbourne, $5^{\text {th }}-7^{\text {th }}$ of February).

Higgins, H. B. (1915) ‘A New Province for Law and Order' Harvard Law Review, 29(1) pp. 13-39.

Holloway, J \& Picciotto, S (eds) (1978) State and Capital: A Marxist Debate, Edward Arnold, London.

Holloway, J (1988) 'The Great-Bear, post-Fordism and class struggle: A comment on Bonefeld and Jessop' Capital \& Class, 12(3) pp. 93-104.

Ivanova, M (2011) 'Consumerism and the Crisis: Wither the 'American Dream'?' Critical Sociology, 37(3) pp. 329-350.

Jessop, B (1988) 'Regulation theory, post Fordism and the state: more than a reply to Werner Bonefield' Capital \& Class, 12(1) pp. 147-168.

Jessop, B (1997) 'Survey Article: The Regulation Approach’ The Journal of Political Philosophy, 5(3) pp. 287-326.

Jessop B. \& Sum, N. L (2006) Beyond the Regulation Approach: Putting Capitalist Economies in their Place, Edward Elgar. 
Jessop, B (2013) 'Revisiting the regulation approach: Critical reflections on the contradictions, dilemmas, fixes and crisis dynamics of growth regimes' Capital \& Class, 37(1) pp. 5-24.

Kay, G \& Mott, J (1982) Political Order and the Law of Labour, The Macmillan Press, London.

Kettell, S (2006) 'Circuits of Capital and Overproduction: A Marxist Analysis of the Present World Economic Crisis' Review of Radical Political Economics, 38(1) pp. 24-44.

Lebowitz, M (2003) Beyond Capital, Palgrave Macmillan, New York.

Lipietz, A (1987) Mirages and Miracles: The Crises of Global Fordism, Verso, London.

Lipietz, A (1992) Towards a New Economic Order, Polity Press, Cambridge.

Lipietz, A (2013) 'Fears and hopes: The crisis of the liberal-productivist model and its green alternative' Capital \& Class, 37(1) pp. 127-141.

Lloyd, C (2002) 'Regime Change in Australian Capitalism: Towards a Historical Political Economy of Regulation' Australian Economic History Review, 42(3) pp. 238-266.

Lloyd, C (2008) 'Australian Capitalism Since 1992: A New Regime of Accumulation?’ Journal of Australian Political Economy, 61 pp. 30-55.

Ludeke, J. T. (1998) 'The Evolving Industrial Relations Regime: The Federal System-19921998’ The Australian Law Journal 72(11) pp. 863-870.

Mack, A (2005) 'Class, Ideology and Australian Industrial Relations' Journal of Australian Political Economy 56 pp. 156-171.

Marx, K (1973) Grundrisse, Allen Lane, London. 
Marx, K (1990) Capital Volume 1, Penguin Classics, London.

Marx, K (2004) 'Wages, Price and Profit' in Selected Writings: Karl Marx \& Friedrich

Engels, Collector's Library, London, pp. 65-137.

Miéville, C (2006) Between Equal Rights: A Marxist Theory of International Law, Haymarket Books, Chicago.

Nadel, H (2002) 'Régulation and Marx' in R. Boyer \& Y. Saillard (eds) Régulation Theory:

The State of the Art, Routledge, London, pp. 28-35.

Neilson, D (2012) 'Remaking the Connections: Marxism and the French Regulation School' Review of Radical Political Economics, 44(2) pp. 160-177.

O’Connor, J (1973) The Fiscal Crisis of the State, St Martin's Press, New York.

Pashukanis, E (1978) Law and Marxism: A General Theory, Ink Links, London.

Peck, J (2010) Constructions of Neoliberal Reason, Oxford University Press, Oxford.

Peetz, D (2006) Brave New Workplace, Allen \& Unwin, Crow's Nest.

Petit, P (1999) 'Structural Forms and Growth Regimes of the Post-Fordist Era' Review of Social Economy, 57(2) pp. 220-243.

Polanyi, K (1944) The Great Transformation, Beacon Press, Boston.

Poulantzas, N (1978) State, Power, Socialism, NLB, London.

Provis, C (1986) ‘Comparative Wage Justice’ Journal of Industrial Relations, 28(1) pp. 2439. 
Quinlan, M (2006) 'Contextual Factors Shaping the Purpose of Labour Law: A Comparative Historical Perspective' in C. Arup et al (eds) Labour Law and Labour Market Regulation, The Federation Press, Sydney, pp. 21-42.

Renner, K (1949) The Institutions of Private Law and Their Social Functions, Routledge \& Kegan Paul, London \& Boston.

Rolfe, M (2003) ‘Antipodean Fordism: Postwar Americanisation down under' in John Wood \& Michael Wood (eds) Henry Ford: critical evaluations in business and management Volume 2, Routledge, pp. 323-353.

Tickell, A \& Peck, J (1995) 'Social regulation after Fordism: regulation theory, neoliberalism and the global-local nexus' Economy and Society, 24(3) pp. 357-386.

Thompson, E. P (1977) Whigs and Hunters: The Origin of the Black Act, Penguin Books, Harmondsworth.

Treuren, G (1997a) 'State theory and the origins of federal arbitration in Australia' Policy, Organisation and Society, 13 pp. 56-81.

Treuren, G (1997b) 'Regulation Theory and Australian Theorising of Institutional Change in Industrial Regulation’ 1997 AIRAANZ Conference, Brisbane, pp. 358-369.

Treuren, G (2000) 'The Concept of the State in Australian Industrial Relations Theory' Labour \& Industry, 11(2) pp. 75-98.

Vidal, M (2013) 'Postfordism as a dysfunctional accumulation regime: a comparative analysis of the USA, the UK and Germany' Work, employment and society, 27(3) pp. 451471. 
Wells, A (1989) Constructing Capitalism: An Ecoomic History of Eastern Australia, 17881901, Allen \& Unwin, Sydney.

Wood, E. M. (2003) Empire of Capital, Verso, London.

Wright, C (1993) 'Taylorism Reconsidered: The Impact of Scientific Management within the Australian Workplace' Labour History 64, pp. 34-53. 